\title{
THE BRITISH VISION OF LAHORE: AN EXAMINATION OF CONCEPTS OF ARCHITECTURE AND URBAN DESIGN THROUGH LITERARY SOURCES
}

\author{
Abdul Rehman* \\ Muhammad Arshad**
}

\begin{abstract}
The British built a new city in the south and southeast of Lahore during their ninety years rule (1849-1947). In this new planned city, new concepts were employed to produce some of the finest specimen of architecture and urban design in the history of the subcontinent. The layout of British Lahore was first conceived by Charles Napier and subsequently detailed urban design projects were prepared for different areas to produce built environment with definite character. To achieve this, new byelaws were introduced for housing and built environment and a debate on architecture was initiated on the possible styles of architecture. Subsequently a variety of concepts was employed in the design of public buildings which were later followed by the common masses. The British Lahore took its real shape with the arrival of Basil M. Sullivan as first Consulting Architect to the Government of Punjab in the first quarter of the twentieth century. The concepts of urban design of the British period have not been discussed in any recent scholarship. This paper will discuss the concepts of architecture and urban design based on the original reports and texts written during the British period. In addition, a detailed philosophy and vision of the British administration has also been discussed which provided a basis for achieving its ultimate shape.
\end{abstract}

Keywords: Colonial architecture, urban design, urban management, landscape.

\section{INTRODUCTION}

The British inherited a Mughal city, the beauty of which was admired both by native as well as the European travelers who visited it in the $16^{\text {th }}$ and $17^{\text {th }}$ century (Abul Fazl, 1989) and William Finch (Foster, 1921) gave a picture of great prosperity of the city in the following words: the streets are "Fair and well paved", the buildings are "fair and high, with brick and much curio site of carved windows and doors", and of course, "the delightful gardens have lent it additional beauty". It was, "resort of people of all countries whose manufactures present the astonishing display and it is beyond measure remarkable in populessness and extant". Mughal emperors, princess and high officials built themselves "lofty and superb edifices", garden retreats and tomb outside the walled city". The walled city had wide bazaars, from where kuchas, a relatively wide street, lead to different mohallas. Narrow winding lanes mostly dead end alleys provided access to residences. The houses were densely packed within the residential neighborhoods. Open drains used to ran in every direction leading to open sewers which ran outside the periphery of the walled city. The drinking water was drawn from wells located within the houses and public streets. After the fall of Mughal Empire, Lahore became capital of the Sikh who ruled the area for almost 100 years. The British travelers who visited Lahore during Ranjit Singh reign described decay and ruinous suburbs (Moorcraft, 1977).

\section{CONCEPTS OF URBAN PLANNING IN GREAT BRITAIN AND INDIA BEFORE BRITISH OCCUPATION}

The nineteenth century was significant in the history of town planning in Europe and its influence was also seen in Lahore. The industrialization created congestion, disease and poverty especially in the working class. New theories of ideal cities were put forward as a social movement for urban reform that arose as a reaction against the disorder of the industrial city. At the same time practical considerations of adequate sanitation, movement of goods and people, and provision of amenities also drove the desire for planning. Contemporary planners seek to balance the conflicting demands of social equity, economic growth, environmental sensitivity, and aesthetic appeal. In England the movement for the improvement of public health facilities started in 1840's but most practical steps put forward in this direction was the introduction of Public Health Act of 1875. The act provided a new foundation for urban planning and management to improve environmental conditions.

* Dr. Abdul Rehman, Professor, Department of Architecture University of Engineering \& Technology, Lahore.

** Muhammad Arshad, Associate Professor, Department of Architecture University of Engineering \& Technology, Lahore. 
The British colonial administration was equally concerned with the sanitary condition in India primarily because of high mortality rate of British troops. Accordingly, planning and public health were linked, with ancestry in the English sanitary movement of the 1840's. Urban planners, most of whom were civil engineers and health professionals, were required to design schemes to improve sanitation conditions in residential areas and work places. Other efforts sought to separate land use activities, especially residential from industrial zones. Military establishments such as cantonments were developed on garden city concepts in the suburbs of historic towns. The history of sanitary work really began with the reports of the Royal Commission of 1859 . The 1863 report described the sanitary conditions of the Army with the remarks that the mortality rate among British troops was 69 per 1000 and recommended the establishment of a Commission of Public Health in each presidency and pointed out the need to improve sanitation and prevention of epidemics in civil society for improving the health of the
British Army. To improve civil sanitary conditions, sanitary boards were formed in each province in 1864 to carry out the inspection of sanitation, supervise vaccinations, maintain vital statistics, and collect meteorological data. Lahore at the time of occupation of British forces had serious environmental problems but at the same time Lahore started expanding in different directions. The epidemics and disease was common in addition to sanitation problems. The British administration had to work in different directions to improve the quality of built environment and to continue to preserve the character of a garden city. These efforts are being discussed in detail in the following pages.

\section{THE BRITISH CONTRIBUTION TO LAHORE}

The British occupied Lahore in 1849 which at that time comprised of Walled City ruins of the Mughal period gardens and few suburban settlements. One of the important task before the British administration was to plan and develop

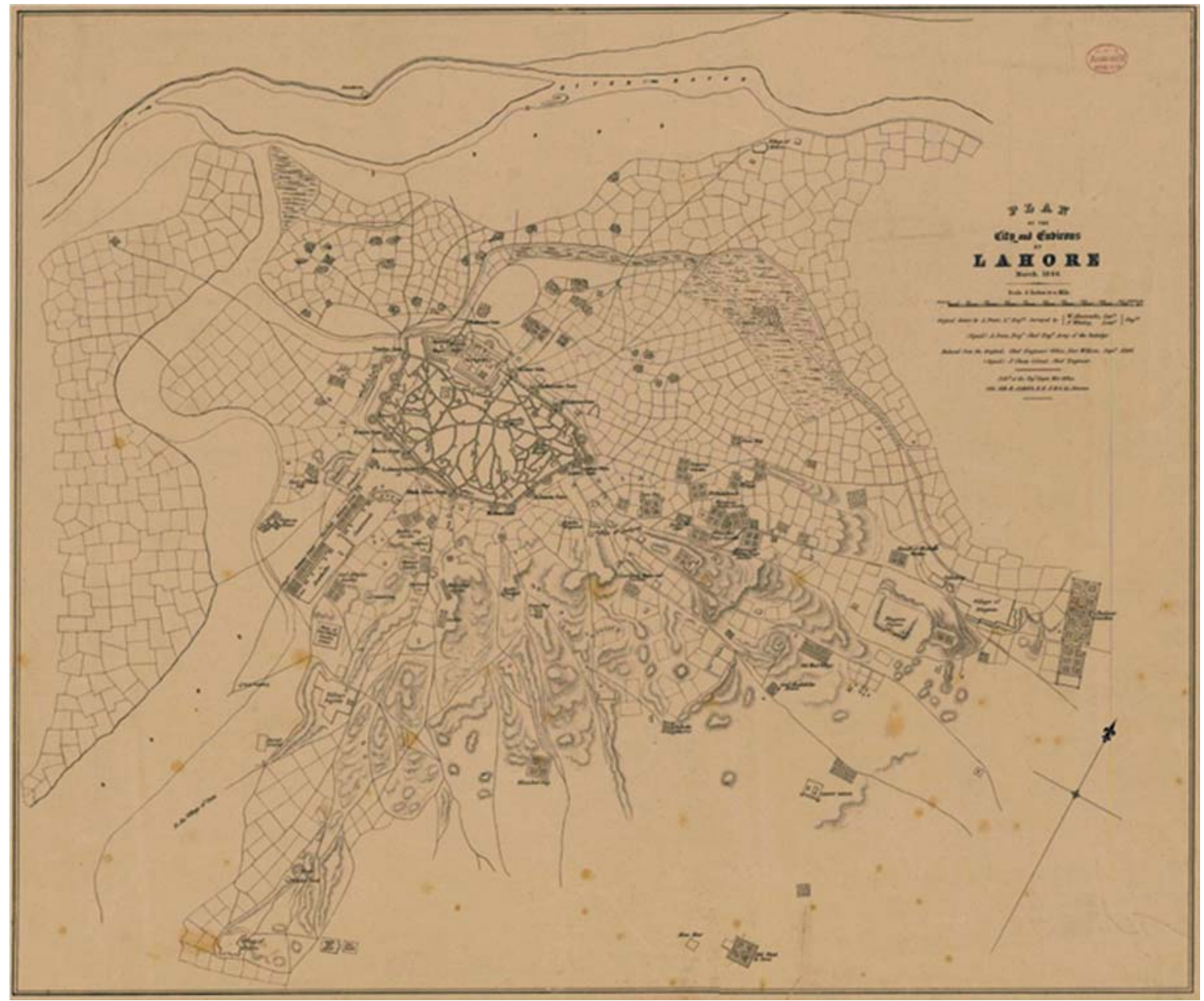

Figure-1: 1845 Map of Lahore showing the routes and important settlements 
such areas where they could provide residential accommodation for the British administration as well as to keep army. Initially the officers were settled in Lahore Fort and tombs located in the suburbs of the walled city. The army was kept in the Lahore Fort and Sikh period barracks near Anarkali. Lt. Colonel Napier prepared the basic outline of the Colonial Lahore in 1851 (Goulding, 1924). In his plan the lower Mall connected Lahore Fort (military establishment) with Anarkali while Upper Mall connected Mian Mir with Anarkali.

The British occupation of Lahore coincided with the period of their greatest material progress and the same was reflected in the development of the city. They succeeded in creating at Lahore a city of having well planned and spacious roads lined with variety of trees. The beginning was made by establishing their administrative headquarter near the tomb of Anarkali where General Ventura and military advisers of the Khalsa army used to reside and decide important military affairs (Lee, 2002). However, residence of Lt. Governor was fixed at its present location of tomb of Kasim Khan. The troops were housed in Anarkali barracks, an old Sikh cantonment. The British soon found this place unhealthy or too near the places of displeasures in many ways which John Lawrence felt very strongly. "Few suburban localities could be found in any province presenting such peculiar sanitary difficulties as the vicinity of Lahore. The station of Anarkali with its adjunct is dotted over an area of several square miles, over which extend the ruins of not one but of several successive cities of various ages and various dynasties. The surface of this extraordinary plain is diversified by mounds, kilns, bricks, stones, broken masses of masonry, decaying structures, hollow, excavations and all the debris of habitations that have passed away. The soil is sterile and impregnated with salt petre, but the ground is interspersed with rank vegetation, and though generally arid yet from its undulating nature possesses an unfortunate attitude for accumulating stagnant water" (Grenfell, 1964). An American artist /painter Lord Weeks described Lahore in the following words:

"There is no lack of hotels at Lahore, considering the smallness of transient population, and, as usual, they are all situated in the civil station, as the European settlement is called....As the European suburb is usually large, these highways, shaded by tall trees of the tamarisk family, have a rather wearisome, sameness, and this impression of monotony is partly due to the somber hues of foliage..... While the English community of Lahore, as elsewhere in India, has elected to live away from the native city, and while the original nucleus of this settlement was planted, for sanitary and other reasons, far from the city walls, it has gradually filled up the intervening space, so that usual neutral ground, or no man's land, has ceased to exist" (Weeks, 1986).

The earliest most important sub-urban contribution made by the British soon after their occupation of Lahore was the development of cantonment on the south east side of the historic city. Lt. Col. Napier decided that the Anarkali cantonment was to be moved away from the city on sanitary grounds (Goulding, 1924). Therefore, the present site was selected and laid out by military engineers. It was planned on grid iron pattern having straight north-south roads bisected by east- west roads. The major north south street was named after British officers while minor east west streets were named after Indian cities of Punjab Province. One of important feature of the plan was an oval park located at the center with the Anglican Church at one end of the oval and tennis grounds at the other. Senior officers lived near the center while subordinate personnel's were accommodated outward from the center in order of decreasing rank. Indian and European troops were separately accommodated north and south of the officer's quarter respectively. Each group was housed according to its rank in identical barracks grouped in blocks of parallel lines. For the convenience of the civilians Saddar Bazaar and Royal Artilary Bazaar was planned in different locations. The artillery and cavalry grounds were two major open areas of the proposed scheme. A large number of trees were planted and irrigated with water drawn from the canal. The cantonment was a "garden city," an idea which became popular in England half a century later than its implementation in Lahore.

In 1852, Bari Doab Canal was excavated which separated the city from the cantonment and brought a landscape change in the city. It became one of the most pleasant features. The canal, with the roads lined with plantation that run along its banks, swing in a great arc from the north east to south west irrigated the lawns of important settlements laid out for British bureaucracy. A channel drawn from the canal also irrigated the circular garden around the walled city. The most important pre-partition settlements founded along the canal were Mayo Garden, railway colonies, Government Officers Residence (GOR).

The British laid much emphasis on the area around cantonment, secretariat and the railway station. The civil lines (Donald Town), Governor House, the Garden started by the Montgomery and the race course, was principal residential and recreational area furnished with clubs, all lay along the cantonment side of the town in the easy reach of the protection required. The roads built to enable the 


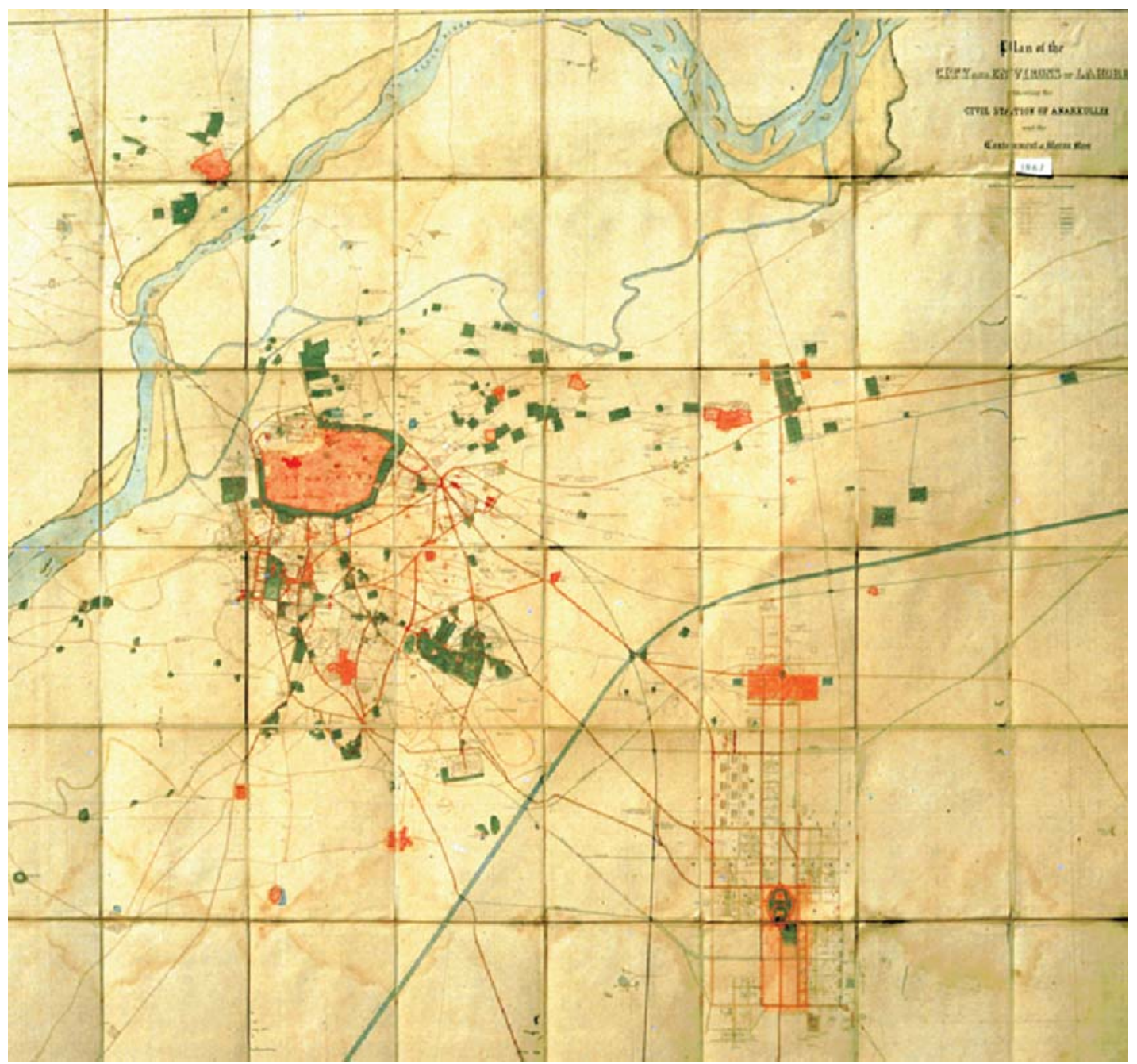

Figure-2: Early British period Map of Lahore Showing Extant Mughal and Sikh period Gardens.

Sahibs to drive sedately from house to office or club or cantonment was superimposed on the indigenous pattern. Grenfell noted that "through deference to local custom or through lack of appreciation of the importance of town planning, it is difficult to say which every bullock track was retained. Indeed the Sahibs, may even have added a few bridle path of their own. No attempt was made to rationalize the requirements of the old and the new. East was east and west was west and that is that" (Grenfell, 1964). The road meant for the British were wide, spacious and lined with trees on both sides. In addition front lawns of the bungalows further added spatial dimension to the landscape. The open spaces and spacious lawns of the railway housing Governor House, Cantonment, Government Officers Residences and Lawrence Garden were irrigated from irrigation channels drawn from canal. Canal as artifact changed the landscape environment of Lahore.

While the new housing areas were taking shape, the improvement of sanitation and provision of safe water supply was considered rigorously. In this connection a resolution was promulgated by the Municipal committee Lahore at a special general meeting held on May $31^{\text {st }} 1876$. The resolution conveyed the intention of the municipality to undertake, subject to necessary sanction of the Government, the erection of the water works so as to ensure pure water supply to the city of Lahore and its suburbs and the construction of an improved and complete drainage and sewerage system for the same localities. For this purpose the services of Mr. Leslie Clark, who had long experience of working in Indian cities, was hired to design and prepare the estimate. Subsequently the work was started and a large 
reservoir was started in the city and opened in 1883-84 (Latif, 1892). The project helped in the provision of safe water supply to residents of walled city. The water tanks were filled through a series of pumps installed near the river bed.

While the concepts of garden city and sustainability were being debated in England, Lahore was equally perusing and implementing such ideas. The concept of sustainability was considered important in both public and private housing schemes. Soon after the establishment of railway workshops in 1912, workshop colonies were established on the east side of the city. These colonies were laid out on grid iron pattern with large bungalows having spacious front and back lawns. The roads generally 40 feet wide were planted with shade trees on both sides. The important feature of this housing scheme was the provision of vegetable and dairy farms to provide fresh food and milk to the residents. Clean water supply and sewerage system was ensured. The lawns were irrigated from city Rajbah (channel) from Bari Doab Canal near Mughalpura (Rehman, 2009).

The most important scheme developed, in this regard, slightly on larger scale was the development of Model Town Lahore. In the early twenties Cooperative Societies Act was passed which enabled independent groups to form cooperative societies and construct their own housing schemes. The most important township in the suburbs of Lahore was built under this act was Model Town. This was one of the most outstanding examples of ideal town built in the early years of $20^{\text {th }}$ century on co-operative basis in the Indian subcontinent both incorporating the ideas of sustainability and the garden city. The idea of this scheme was a brain child of Diwan Kham Chand, a lawyer of Lahore. He published his idea in January 1921. "My scheme", he expressed, "is that within easy reach of Lahore, say within 6 or 7 miles of it, about 1,000 acres of agricultural or waste land be purchased, and on it by built a town with all the conveniences of modern times" (Aijazuddin, 2003, Chand, 1921).

Model Town achieved a mark of success due to its innovative byelaws and therefore became one of the best housing scheme in the Indian subcontinent. In 1927 Bogle writes, "In Lahore a garden City has recently been started by a cooperative society, and an area laid out for residential houses in an endeavor to provide ideal homes; this 'Model Town' as it is called, has its first two byelaws, (1) That every house shall have a garden; (2) That of the total area of the plot not less than two third shall be garden and not more than one-third built over. No better rules can be imagined for ensuring a delightful residential area, cool attractive and healthy, and, where it is possible to enforce such rules, a municipality could not do better than adopt them" (Bogle, 1929).

\section{URBAN DESIGN AS A PROFESSION}

Twentieth century was a turning point in which the role of an architect became much more crucial. With the introduction of a more comprehensive Municipal act of 1911 every owner of a plot was bound to submit building plan for the approval of the municipal committee. The Improvement Trust Act of 1922 and establishment of Lahore improvement trust further imposed checks on the urban growth of Lahore. The municipal committee was asked to submit large schemes to the trust for approval the consulting architects to the government of Punjab prepared most important urban design schemes.

Patrick Geddes, a scot botanist also admired Sullivan's contribution in the following words: "I am glad to find that improvements of some of the defects in the network of roads are already in active progress. Beginning with Charring Cross, I have nothing but approval of the new layout, and congratulate Mr. Sullivan accordingly. His improvement of the mall as its crossing with Maclagan Road is also, I like it, the best that could be made of that difficult situation." He further stated that "While we are discussing the improved aspect, as well as convenience and safety, of the fine thoroughfare of Civil Station, one cannot but ask - How comes it, that with all this real interest in this fine modern city, and even pride - for instance, the improvement of the Charring Cross" (Geddes, 1917).

Twentieth century was a turning point in which the role of an architect became much more crucial. With the introduction of a more comprehensive Municipal act of 1911 every owner of a plot was bound to submit building plan for the approval of the municipal committee. The Improvement Trust Act of 1922 and establishment of Lahore improvement Trust further imposed checks on the urban growth of Lahore. The municipal committee was asked to submit large schemes to the Trust for approval the consulting architects to the government of Punjab prepared most important urban design schemes. This created their lasting impression on the built environment. The layout of major crossing and urban design schemes of important square were handled carefully before actual implementation. The consulting architect designed building for both government and private clients to achieve a meaningful built environment having both quality and character. In this case the Charring Cross Schemes and Prince Albert Victor Scheme (Nila Gumbad area) can be 


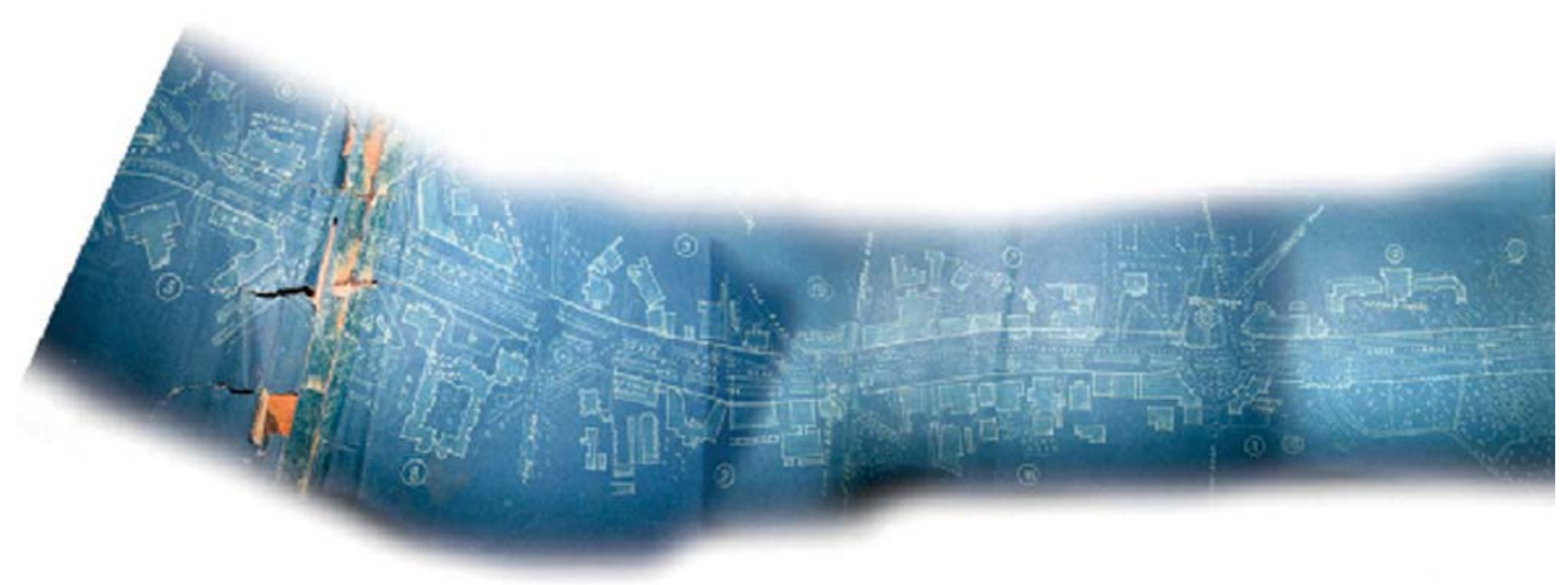

Figure-3: Part Plan of the Mall Lahore (1928) showing the alignment of buildings and squares designed by Basil Sullivan.

sited as important examples, a true and positive meaningful urban space with a strong architectural character can only be created if there is a single architect who is preparing the layout and designing the buildings around it.

The encroachments were strictly controlled everywhere including in the walled city. Comprehensive mapping were undertaken and detailed proposals were prepared for the urban improvement. For the first time conservation proposals were prepared to improve quality of life in the historic walled city. The urban expansion all over towns in Punjab led to the creation of the post of town planners. He prepared master plan of Lahore and designed or scrutinized a number of schemes. But the dominating role of consulting architects remained crucial throughout the first half of the 20th century. This is the reason why we admire the quality of urban spaces in colonial Lahore.

Beside all these initial effort in urban development, the British did not care the Mughal landscape of Lahore rather they destroyed it to suit their own requirements. The most important case associated with this is the development of railway network. Beginning from construction of Lahore railway station in 1859-60, Multan-Lahore railway line and Lahore-Gujranwala railway line were laid in 1861 and 1881 respectively. The Multan railway line connected cantonment with Lahore city but it bifurcated Mian Mir area into two parts. The Mullah Shah and Khwaja Bihari tomb garden were separated from Nadira Begum and Mian Mir tomb. Similarly along Gujranwala railway line, Nur Jahan tomb was separated from Jahangir and Asif Khan Tomb complex.

\section{URBAN CONSERVATION IN LAHORE}

In 1904 an act for the preservation of Ancient Monuments was passed. According to the Act a well-conceived scheme was prepared for both the conservation of buildings which had escaped destruction and the exploration of archaeological sites which remained untouched by this time. Both dutiesconservation and exploration were entrusted to a skilled Director-General of Archaeology, aided by a staff of expert assistants in the provinces, and supplied liberally with funds. The Department thus, did admirable work, and its reports become more and more interesting every year.

Basil Martin Sullivan served as consulting architect to Government of the Punjab from 1913-1938 and made significant architectural contributions and improvements in every part of the city. From 1924-26, a complete survey of Lahore was carried out by him and prepared the very first ever comprehensive conservation plan of the Walled City in 1929 entitled "A note for the use of the Lahore Improvement Trust Committee and of the Lahore Improvement Trust when formed, With special reference to the City of Lahore inside the walls" (Sullivan: 1929). The most serious problems he found were congestions, heaps of debris, domestic animals and encroachments. Therefore, a number of suggestions were made to improve the situation. He proposed a dairy form outside the walled city to transfer the animals to keep the walled city clean. He also felt concern over the overhead cables which changed the visual character of historic streetscapes. 


\section{MASTER PLANNING IN LAHORE}

By the year 1940 Lahore had expanded in every direction. New housing schemes come up in every direction. The vacant areas in and around older settlements almost got filled with private housing schemes. The railway workshops brought a significant change and new industries begin to grow particularly in the northern part of Lahore. Additional areas were required to house educational institutions. There was a lot of pressure to accommodate new facilities. This required a comprehensive master planning. In this situation Aylmer Coates, provincial town planner to the Government of the Punjab proposed the first master plan for the development of Lahore (Coates, 1944).

The master plan was published in "Memorandum on Town Planning" in 1944. The important concerns addressed in the plan were with questions of congestion, unplanned growth and ribbon development along major roads. His report discussed the problem of existing and new residential settlements, location of Industries and made recommendation for future development. This map gives the proposed outline for future development of Lahore. The major industrial area suggested in the plan was around Pakistan Mint between Bari Doab Canal and Grand Trunk Road.

\section{CONCEPTS IN ARCHITECTURE}

In the early years of British rule the services of architects were hired either from England or other provinces of British India who had no sympathy with the local architecture. The architects took inspiration from the English or classical architecture rather taking lessons from grand tradition of Indian architecture. The most important structures in this regards are Lahore Church of resurrection, Government College, Lahore Railway station and Mayo Hospital. The church was designed by John Oldrid Scott, son of Sir George Gilbert Scott in Early English decorated style (Latif, 1892). Both father and son were specialist in designing churches and cathedrals. Mr. Oldrid Scott was requested to draw new plans by adapting foundations of existing church as far as possible. Gothic pointed arches, flying buttresses, two towers with gable roof were the main feature of architecture. Similarly Government College Lahore was also inspired from gothic architectural tradition.

On the other hand there were few architects who designed buildings in Indo Saracenic architectural style. Completed in March 1889, Punjab High Court building was the most outstanding structure of this category. The building was designed by J. W Brossington, Consulting Architect from
Madras (Latif, 1892). The architect had strong inspiration from the works of Robert Fellowes Chisholm. This quadrangle building was built in burnt bricks using lime mortar. Special molded bricks were used in cornices, moldings, friezes, overhangs and other decorative features such as jails (trellis) to fill the upper portion of arches. The roof of the main court rooms is double pitched supported on wooden trusses and covered with clay tiles. The ogee shaped pointed engrailed arches have been used throughout the building. The main feature of the building is the central portion which has a porch in the front and naqqar khana gallery on its rear side. It is flanked by two towers having square base and projecting eaves at the top over which rise circular shaft having flutes inspired from Qutb Minar. It is finally topped with projecting balconies over which rest domed pavilion. A muqarnas cornice runs along the arcaded verandah. Within the structures both element from European and local indigenous architecture have been used. The elements are very neatly detailed out in a fine proportion. These building set strong examples of two different streams of architectural styles both designed by the British architects.

The twentieth century began steadily but development activities continued. John Beggs, Consulting Architect to Government of India, designed large number of projects in Lahore which include Physics and Biology Departments at Government College, Veterinary College, Railway Church on Empress Road and Time Keeper Office in Mughalpura. In addition a number of small housing projects were undertaken by the local architects throughout the town particularly in Gwalmandi and in Donald Town. John Begg in a report to the Government of India in a note to a Report on Modern Architecture wrote: “....The art though still living is dormant. Is it worth reawakening? Should we allow it to die the natural death that from one cause or another has overtaken nearly all similar art traditions in other countries or should we try to give it a new lease of life?" I think.... The living tradition is an artistic asset of such incalculable value that we cannot afford to allow it to die out; that it is well worth reawakening even though the complete process should be lengthy and interim results not acceptable may be to all" (Begg, 1913).

The buildings designed so far followed a variety of styles. There was an utter confusion among the architects as what should be appropriate architecture of Lahore. As a result a debate was initiated among the architects. There were two main schools of thought; the aesthetic imperialists and the revivalists of indigenous architecture. The former argued that the British should seek to emulate the Romans and impose British architecture with confidence. They were 


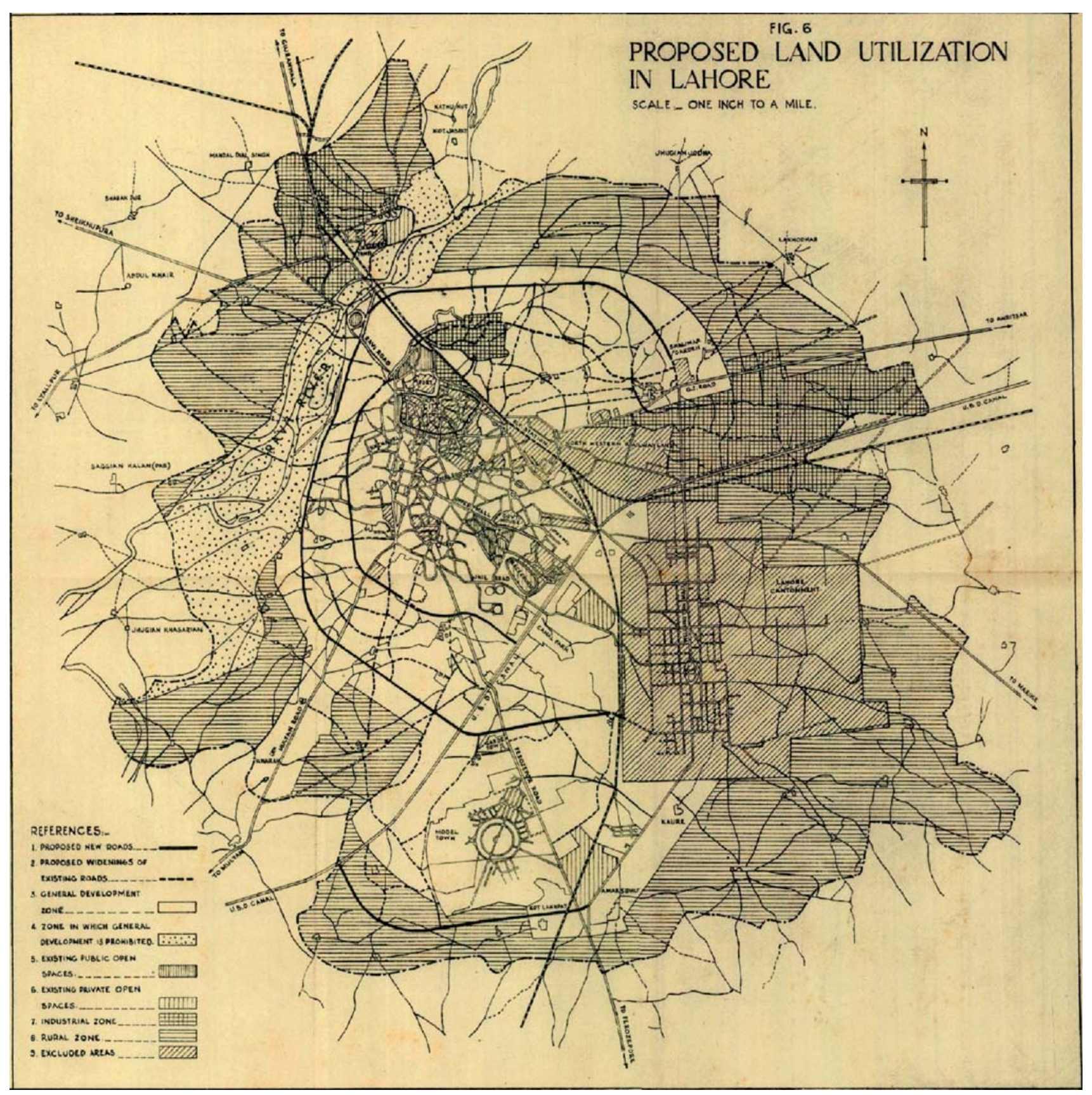

Figure-4: Proposed Land Utilization (1845) by U. Aylmer Coates. 
opposed by the revivalists who thought that uninterrupted living tradition existing in architecture, connecting the present and the past should continue. The true policy should be to discard all imported forms and ideas, and to foster living traditions by sustaining the local master builders, whose craft, skills and expertise were in danger of dying out from lack of patronage. The architecture of Lahore is the outcome of these schools.

In this scenario Bhai Ram Singh started contributing towards the revival native tradition with the support of John Lockwood Kipling (Vandal and Vandal, 2006). From 1880 to 1911, Lahore has witnessed Bhai Ram Singh as one of the most creative and innovative architects in its history. He has produced a number of most prestigious buildings in fair face brickwork. Born in Jullundur in 1858, he got his initial training in carpentry 1874 and a year later he got enrolled at Mayo School of Industrial Arts. During his stay at Mayo School he participated in a number of exhibitions with his furniture products. John Lockwood Kipling, Principal Mayo School of Arts discovered the talent of this young man and gave him special tasks. In 1881-82 Bhai Ram Singh did first architectural project of the design of Mayo School of Arts under the direction of J. L. Kipling. He was now been consulted for prestigious projects. He designed Khalsa College Amritsar, interior of the Durbar hall (Indian Room) at Osborn House in England. His real professional career started in 1894 when he was appointed Drawing and Carpentry Master and officiating Vice Principal of Mayo School of Arts in 1894 and subsequently as Principal Mayo School of Arts Lahore.

There is a long list of Projects undertaken by him in Lahore, Amritsar, TaranTaran, Srinagar and Peshawar, Lyallpur, Simla, Nabha State etc., but the most important buildings he designed in Lahore are main building of Chiefs College, later Aitchison College (designed 1886 construction completed 1890), Mayo School of Arts and Museum (188889), Albert Victor Wing of Mayo Hospital (1890), Boarding House of Government College (1889-90) Punjab National Bank, Anarkali (1904), Punjab University Senate Hall ((1905), Punjab University Library (1910), Queen Mary College (1910), Chamba House (Between 1912-14). Aitchison College was his largest project in which he designed Gurdwara, Mandir, Gymnasium, Three Boarding houses, Bahawalpur House, Principal and Vice Principal House from (1890-1907). One of the most inspiring elements of his work was his unity of concept throughout the building. He rigorously maintained the same design vocabulary in the interior as well as exterior. He handled brick like a soft wood and executed even minute details to its mastery. A variety of specially molded as well as carved bricks were used throughout the buildings to achieve the desired objective. He very well understood the potential of local materials, drew inspiration from traditional architecture and produced works with its own distinctive style which can be ranked among the finest work of the British.

\section{CONCLUSIONS}

The British contribution in architecture and urban design was most comprehensive and considered most crucial in shaping the built environment. In terms of urban design, projects were specially handled. This includes the layout planning as well as design of buildings by the same architect to create a meaningful urban environment. Architect in the public sector designed buildings for the public sector projects as well as for private clients. The private clients were then forced to implement these projects. The second important contribution was the creation of definite architectural character of streetscape. In this regards, the layout of the building and complete architectural detailing were conceived and implemented. In addition to the Mall Road, the buildings and squares on other roads were also dealt in a similar manner. The third important contribution was the preparation of byelaws for the housing schemes and buildings. These byelaws were strictly implemented. The sanitary aspects and light and ventilation in buildings were important considerations. Conservation of walled city for the creation of an improved living was another important area which received special attention. In addition, Mughal period monuments were restored and conserved, environmental resources were preserved and maintained. The canal water was used in the irrigation of lawns and open spaces. Comprehensive sanitation and water supply schemes were prepared for the improvement of urban environment. Finally, comprehensive master plan of Lahore was prepared and implemented. A complete land use proposal was made in which industrial areas were segregated from residential areas. In short, comprehensive planning based upon strong vision was undertaken and implemented faithfully. 


\section{References}

Abul Fazl. Ain-e Akbari, (1891) Vol. II, Trans. Colonel H. S. Jarrett. Asiatic Society of Bengal, Calcutta.

Aijazuddin F. S, (2003) Lahore Recollected: An Album, Sang-e-Meel Publications, Lahore.

Begg, John, Consulting Architect to Government of India, December 1912. Note on the Development of Indian Architecture, in Report on Modern Architecture by Sanderson, Gordon under the direction of Dr. J. H. Marshall, Director General of Archaeology in India, published Government Press, Allahabad, 1913

Bogle G. M. Linton. (1929) Town Planning in India, Oxford University Press, London.

Chughtai, Abdullah, M. (1975) Masjid Wazir Khan, KitabKhana Nauras, Lahore.

Foster, William. (1985) Early travels in India: 1538-1619. Oriental Books Reprint Corp. Delhi, .pp.117-118.

Geddes. (1917) Patrick Town Planning in Lahore: A Report to the Municipal Council. Commercial Printing Works, Lahore, pp.28-29.

Goulding H. R. (1924) Old Lahore: Reminiscences of a resident. Universal Books Lahore, pp.30.

Latif. S. M. (1892) Lahore: Its History, Architectural Remains and Antiquities. New Imperial Press, Lahore, p.187.

Lawrence, Sir J. (1851) Selection from the records of the Government of India (foreign Department), for the years 185152 and 52-53, relating to the administration of Punjab territories.

Lee, H. (2002) Brothers of the Raj: The Lives of John and Henry Lawrence, Oxford University Press.

Rehman, N. (2009) From Site to Artifact: Canal in the City of Lahore. Unpublished SMArch Thesis, Massachussetts Institute of Technology, Cambridge.

Sullivan Basil M. (1929) A note for the use of the Lahore Improvement Trust Committee and of the Lahore Improvement Trust when formed, with special reference to the City of Lahore inside the walls, Lahore.

Vandal, P. and Vandal, S. (2006) Lahore, Raj and Bhai Ram Singh.National College of Arts Publication, Lahore. 